\title{
EFFECTIVENESS OF CONSUMING DECOCTION OF BAY LEAVES (SYZYGIUM POLYANTHUM) AND SOURSOP LEAVES (ANNONA URICATA) ON REDUCING URIC ACID LEVELS IN ELDERLY IN GROBOGAN, CENTRAL JAVA
}

\author{
Dewi Rukmana", Purhadi", Wahyu Riniasih" \\ "Master Program in Public Health, Universitas Negeri Semarang \\ ${ }_{2}^{2}$ School of Health Sciences An Nur Purwodadi
}

\begin{abstract}
Background: Gout remains a common health problem of elderly. Uric acid occurs due to excessive consumption of purines. Alternative therapy using herbal which contains uric acid reducing agents can be considered the treatment for gout. Syzgium Polyantum and Annona Muricata $L$ leaves are found the component of flavonoids, tannins, and essential oils with citrate oil and eugenol which can reduce uric acid levels. This study aimed to examine the effectiveness of consuming decoction of bay leaves (Syzygium polyanthum) and soursop leaves (Annona uricata) on reducing uric acid levels in elderly in Grobogan, Central Java.

Subjects and Method: A quasi-experimental with pretest and posttest control group design conducted at Purwodadi, Central Java. A sample of 20 elderlies was selected for this study and allocated into two groups: (1) Experimental group that received decoction Bay leaves (Syzgium polyanthum) and Soursop leaves (Annona Muricate L), and (2) Control group that received no intervention. The dependent variable was uric acid level in elderly. Uric acid level was measured by digital blood uric acid test. The independent variables were consuming decoction Bay leaves (Syzgium polyanthum) and Soursop leaves (Annona Muricate L). The data were analyzed by Mann-Whitney test.

Results: Bay and Soursop leaves had effect to reduce the uric acid level in elderly. After the intervention, mean of the Bay leaves (Mean=7.40; $\mathrm{SD}=13.60$ ) was lower than the Soursop leaves (Mean=13.60; $\mathrm{SD}=0.57)$, and it was statistically significant $(\mathrm{p}=0.018)$.

Conclusion: Bay and Soursop leaves have the effect to reduce the uric acid level in elderly. There is significant mean difference in effectiveness of Bay and Soursop leaves.
\end{abstract}

Keywords: uric acid, Annona Muricate L, Syzgium polyanthum, elderly

\section{Correspondence:}

Dewi Rukmana. Master Program, Universitas Negeri Semarang. Gedung B 202 Pascasarjana UNNES, Kelud Utara III Petopon Gajah Mungkur, Semarang, 50273. Email: dewirukmana737@students.unnes.ac.id. Mobile: +6285726418732.

The $7^{\text {th }}$ International Conference on Public Health Solo, Indonesia, November 18-19, 2020 398 https://doi.org/10.26911/the7thicph.05.30 